NASA/TM-2000-210477

AIAA-2000-3413

\title{
Mission Advantages of Constant Power, Variable Isp Electrostatic Thrusters
}

Steven R. Oleson

Glenn Research Center, Cleveland, Ohio 
The NASA STI Program Office ... in Profile

Since its founding, NASA has been dedicated to the advancement of aeronautics and space science. The NASA Scientific and Technical Information (STI) Program Office plays a key part in helping NASA maintain this important role.

The NASA STI Program Office is operated by Langley Research Center, the Lead Center for NASA's scientific and technical information. The NASA STI Program Office provides access to the NASA STI Database, the largest collection of aeronautical and space science STI in the world. The Program Office is also NASA's institutional mechanism for disseminating the results of its research and development activities. These results are published by NASA in the NASA STI Report Series, which includes the following report types:

- TECHNICAL PUBLICATION. Reports of completed research or a major significant phase of research that present the results of NASA programs and include extensive data or theoretical analysis. Includes compilations of significant scientific and technical data and information deemed to be of continuing reference value. NASA's counterpart of peerreviewed formal professional papers but has less stringent limitations on manuscript length and extent of graphic presentations.

- TECHNICAL MEMORANDUM. Scientific and technical findings that are preliminary or of specialized interest, e.g., quick release reports, working papers, and bibliographies that contain minimal annotation. Does not contain extensive analysis.

- CONTRACTOR REPORT. Scientific and technical findings by NASA-sponsored contractors and grantees.
- CONFERENCE PUBLICATION. Collected papers from scientific and technical conferences, symposia, seminars, or other meetings sponsored or cosponsored by NASA.

- SPECIAL PUBLICATION. Scientific, technical, or historical information from NASA programs, projects, and missions, often concerned with subjects having substantial public interest.

- TECHNICAL TRANSLATION. Englishlanguage translations of foreign scientific and technical material pertinent to NASA's mission.

Specialized services that complement the STI Program Office's diverse offerings include creating custom thesauri, building customized data bases, organizing and publishing research results ... even providing videos.

For more information about the NASA STI Program Office, see the following:

- Access the NASA STI Program Home Page at http://www.sti.nasa.gov

- E-mail your question via the Internet to help@sti.nasa.gov

- Fax your question to the NASA Access Help Desk at 301-621-0134

- Telephone the NASA Access Help Desk at 301-621-0390

- Write to:

NASA Access Help Desk NASA Center for AeroSpace Information 7121 Standard Drive Hanover, MD 21076 
NASA/TM-2000-210477

(1953)

\section{Mission Advantages of Constant Power, Variable Isp Electrostatic Thrusters}

Steven R. Oleson

Glenn Research Center, Cleveland, Ohio

Prepared for the

36th Joint Propulsion Conference and Exhibit

cosponsored by the AIAA, ASME, SAE, and ASEE

Huntsville, Alabama, July 16-19, 2000

National Aeronautics and

Space Administration

Glenn Research Center 
Trade names or manufacturers' names are used in this report for identification only. This usage does not constitute an official endorsement, either expressed or implied, by the National Aeronautics and Space Administration.

Available from

NASA Center for Aerospace Information

7121 Standard Drive

National Technical Information Service 5285 Port Royal Road

Hanover, MD 21076

Price Code: A03

Springfield, VA 22100

Price Code: A03

Available electronically at http://gltrs.grc.nasa.gov/GLTRS 


\title{
Mission Advantages of Constant Power, Variable Isp Electrostatic Thrusters
}

\author{
Steven R. Oleson* \\ National Aeronautics and Space Administration \\ Glenn Research Center \\ Cleveland, Ohio 44135
}

\begin{abstract}
Electric propulsion has moved from stationkeeping capability for spacecraft to primary propulsion with the advent of both the Deep Space One asteroid flyby and geosynchronous spacecraft orbit insertion. In both cases notably more payload was delivered than would have been possible with chemical propulsion. To provide even greater improvements electrostatic thruster performance could be varied in specific impulse, but kept at constant power to provide better payload or trip time performance for different mission phases. Such variable specific impulse mission applications include geosynchronous and low earth orbit spacecraft stationkeeping and orbit insertion, geosynchronous reusable tug missions, and interplanetary probes. The application of variable specific impulse devices is shown to add from 5 to $15 \%$ payload for these missions. The challenges to building such devices include variable voltage power supplies and extending fuel throughput capabilities across the specific impulse range.
\end{abstract}

\section{Introduction}

The mission benefits of advanced electric on-board propulsion technology are typically great and often enabling. Reducing the on-board wet propulsion system mass requirement can either decrease spacecraft launch mass or increase payload capability. In addition, greater demand can be placed on the propulsion system including increased repositions or longer duration orbit maintenance, increasing useful life.

Past works have shown that for earth orbital and interplanetary missions, Hall and ion electrostatic thrusters can substantially increase payload masses and/or decrease launch costs. ${ }^{1-5}$ On-board propulsion functions for such spacecraft include insertion, orbit maintenance, repositioning, and de-orbit. Currently Hall thrusters operate at a specific impulse $\left(I_{\text {sp }}\right)$ of 1500 seconds, while ion thrusters typically perform at 3000 to 3800 seconds. Each propulsion system provides better mission performance for different missions, with the lower $I_{s p}$ Hall being best for quick orbit insertion and earth transfer missions and the higher $I_{s p}$ ion being better for orbit maintenance and interplanetary missions. Some existing, as well as future, spacecraft require several mission phases of both classes of missions. It has even been proposed to put both Hall and Ion thrusters on spacecraft to make the most of each class of mission. This, however, may be a costly option in terms of mass, complexity and spacecraft design.
Both the Hall and the ion devices have been shown to operate in the other's respective $I_{s p}$ range, although at lower efficiencies. ${ }^{6.7}$ Figure 1 shows this difference in efficiency versus $I_{s p^{\circ}}$. The consequences of pushing each thruster's $I_{s p}$ into the other's range include modified power propulsion units and lifetime concerns.

Hall thrusters operating at higher specific impulses exist in laboratory form as both single and two stage devices. Both use higher voltages (above the nominal 300 volts) to accelerate the plasma ions to even higher speeds. The two stage device has a lower voltage first stage to create the ions and provide a first stage of acceleration and a higher voltage second stage to accelerate the ions to even higher speeds. Ion laboratory devices may be tuned to operate at lower specific impulses, but often at the expense of lifetime. Such Variable $I_{s p}$ Propulsion Systems (VIPS), both Hall and ion, promise to outperform current Hall and ion thrusters as well as provide propulsion for new classes of missions.

This paper will cover how such variable $I_{s p}$ devices would improve several sample mission categories. Sample missions categories to be analyzed are geosynchronous earth orbit (GEO) spacecraft, earth orbit transfer tugs, and interplanetary spacecraft. The high $\mathrm{I}_{\mathrm{sp}}$ portions of the missions are those that are either not time constrained, such as stationkeeping, or require interplanetary maneuvers. The low $I_{\mathrm{sp}}$ portions are

*Senior Member AIAA 
those missions where shorter trip times are needed, especially in earth orbit. Results will indicate what payload or trip time gain is possible with a variable $I_{s p}$ Hall or Ion thruster when compared to current propulsion technologies for all the missions assessed. A review of the resulting mission requirements on each technology will also be discussed.

\section{System Assumptions}

This paper assumes that the creation of a variable $I_{s p}$ (at constant input powers) Hall and Ion thruster is possible, with sufficient lifetimes to complete the various mission phases. Performance of such devices is based on existing laboratory devices, which vary their $I_{s p}$ by changing input parameters such as flow rate, current and voltage inputs. ${ }^{6.7}$

The high $I_{s p}$ Hall performance is extrapolated from current data from the two-stage D-80 Hall thruster device which can be run in either a single stage or two stage mode. ${ }^{\circ}$ A throttleable cathode providing $5 \%$ of the anode flow was assumed for the D-80 calculation. The low $I_{s p}$ ion thruster operation is based on tests on the $30 \mathrm{~cm}$ Ion thruster by Patterson. ${ }^{7}$ The state-of-art Hall and ion thrusters will be limited to specific impulses in their state-of-art ranges, 1500 seconds and 3000-3800 seconds, respectively. These state-of-art thrusters are loosely based on the SPT-100 Hall and the XIPS-25 ion thrusters. Both the state-of-art and VIPS efficiency versus $I_{s p}$ performance is shown by the curves in figure 1 and are fit by the relationship:

Thruster Efficiency $=\left(b^{*} c\right) /\left(c^{\wedge} 2+d^{\wedge} 2\right)$

Where $\mathrm{c}=\mathrm{I}_{\mathrm{sp}} * \mathrm{~g}_{0}, \mathrm{~g}_{0}=9.81 \mathrm{~m} / \mathrm{s}^{\wedge} 2$

For the Hall thruster $b=0.730, d=10400$ and for the ion thruster $b=0.825, d=14570$.

Power processing unit (PPU) efficiency will be assumed to be a constant $92 \%$, regardless of thruster type. It is also assumed that the thruster system mass of a variable $I_{s p}$ system is similar to the single $I_{s p}$ system as a first approximation.

The major design challenges of creating a thruster with constant power but variable $I_{s p}$ operation include building power processing units which can provide varied voltage outputs and thrusters with sufficient lifetimes at high and low specific impulses. These issues will be discussed at the end of the paper after the advantages and operational requirements for each mission have been established.

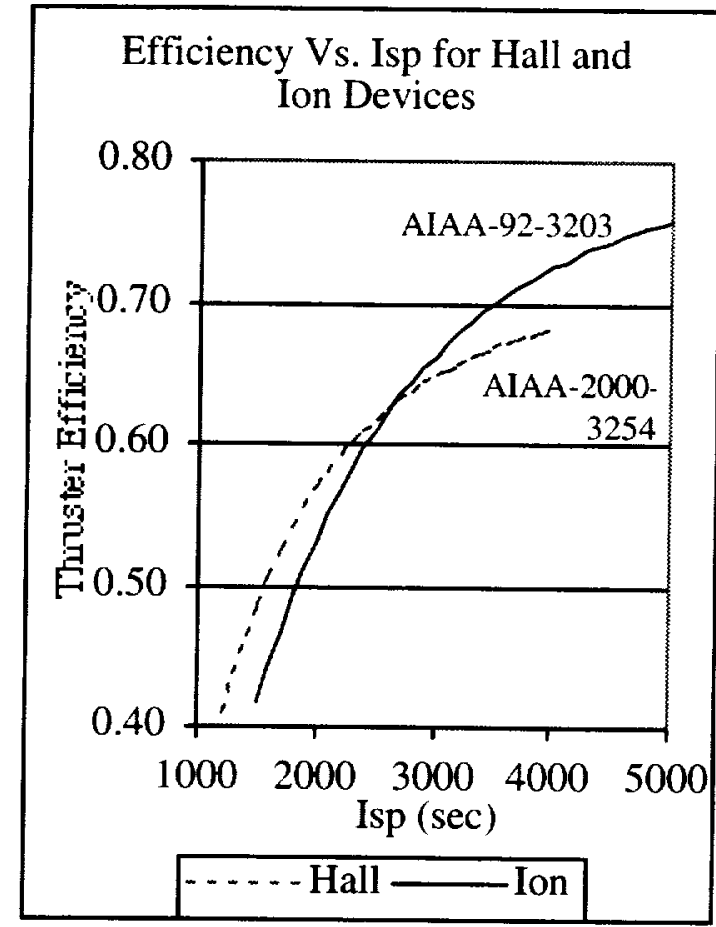

Figure 1. Assumed efficiency vs. Isp.

\section{Mission Assumptions}

Each of the following missions are based on past work but utilize the single point or variable $I_{s p}$ Hall or Ion thrusters assumed above. Some simplified analysis techniques have been used but should still show the relative difference in performance of the single and variable $I_{s p}$ devices.

\section{Combined Chemical/Electric GEO Missions}

Solar Electric Propulsion (SEP) geosynchronous spacecraft mission duties have recently been expanded to include orbit insertion in addition to stationkeeping. In the past SEP was used for just stationkeeping of geosynchronous satellites, including hydrazine arcjets on several Lockheed Martin spacecraft, XIPS-13 thrusters on Hughes 601 spacecraft and SPT-100 Hall thrusters on the Russian GALS and Express spacecraft.' Hughes recently demonstrated the use of electric propulsion for part of the orbit insertion to increase their HS-702 spacecraft payload. The use of electric propulsion, to perform some portion the geosynchronous orbit insertion, has been shown to be advantageous in many past works. ${ }^{2,3,8-12}$ The benefits of using electrostatic Hall or ion propulsion for orbit insertion compared to state-of-the-art chemical systems can be anywhere from $15 \%$ to $45 \%$ payload increase for 30 to 60 day insertion times and $10 \mathrm{~kW}$ to $25 \mathrm{~kW}$ total power levels. ${ }^{3.11}$ 
Past studies showed that the ion thrusters provide more payload than the Hall thrusters for the stationkeeping (SK) phase of the mission due to a much higher $I_{s p}{ }^{3}, 11$ For GEO stationkeeping missions burn time is less important. The same studies also showed that Hall thrusters delivered more payload than ion thrusters for similar orbit insertion times. This is due to the higher thrust of the Hall system, enabling it to start electric propulsion operations at a lower altitude where launch vehicle capability is much better. For fixed trip times the Hall thruster can perform a larger orbit raise. When the two missions were combined the Hall thruster usually outperformed the ion system slightly in delivered payload since the orbit insertion phase of the mission required the larger energy change $(\Delta V)$.

Further improvements in payload are available by having both the ion and Hall thruster operate more closely to the better performing I for each mission phase. High specific impulses $(3000$ to $5000 \mathrm{sec})$ provide better stationkeeping performance with reasonable daily burn times $(<1 \mathrm{hr})$. Lower specific impulses (1500 to $2000 \mathrm{sec}$ ) provide better payload performance for fixed orbit insertion times on the order of a one to three months. The following analysis will demonstrate the potential payload benefit of variable $I_{s p}$ Hall and ion thrusters compared to today's single $I_{s p}$ set-point thrusters. For a complete description of the orbit insertion techniques see references 3 and 11 .

The geosynchronous orbit insertion and stationkeeping sample mission is chosen as starting on a Atlas IIAR with a reduced fuel load chemical apogee system and a $20 \mathrm{kw}$ payload power available to the ion or Hall propulsion system. The Atlas upper stage places the spacecraft into a high elliptical geosynchronous transfer orbit. After upper stage separation, the reduced fuel on-board chemical stage performs burns to place the spacecraft in a less inclined elliptical orbit with the apogee above geosynchronous orbit and the perigee just above the proton radiation belts as shown in Figure 2. Shading is assessed in this analysis while solar array degradation is assumed negligible due to the high starting orbit. The propulsion system assumptions are shown in Table 1.

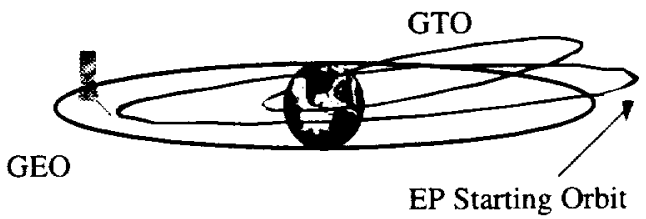

Figure 2. Orbit insertion.

Table 1. Geosynchronous system parameters.

\begin{tabular}{|c|c|c|}
\hline $20 \mathrm{~kW}$ GEO Systems & Ion & Hall \\
\hline $\begin{array}{c}\text { Power into Power } \\
\text { Processor (per thruster) }\end{array}$ & $5.0 \mathrm{~kW}$ & $5.0 \mathrm{~kW}$ \\
\hline $\begin{array}{c}\text { Per Thruster Mass incl } \\
\text { gimbal,support,controller }\end{array}$ & $13.8 \mathrm{~kg}$ & $11.3 \mathrm{~kg}$ \\
\hline $\begin{array}{c}\text { PPU, Feed System, } \\
\text { Cabling, Thermal }\end{array}$ & $8.6 \mathrm{~kg} / \mathrm{kW}$ & $9.0 \mathrm{~kg} / \mathrm{kW}$ \\
\hline Xenon Tankage & 0.1 & 0.1 \\
\hline $\begin{array}{c}\text { Stationkeeping Cant Angle } \\
\text { from orbit normal }\end{array}$ & $30^{\circ}$ & $45^{\circ}$ \\
\hline
\end{tabular}

Cant angles for the Hall and ion systems are assumed to be $45^{\circ}$ and $30^{\circ}$ with respect to the orbit normal (north or south direction for a geosynchronous spacecraft), respectively, for stationkeeping burns to minimize spacecraft interactions. While plume divergence (and thus required cant angle) might be reduced with the use of higher specific impulses, $45^{\circ}$ and $30^{\circ}$ are still assumed for the Hall and ion VIPS, respectively. The thrusters are assumed to be gimbaled to be pointing in the orbit plane for the orbit insertion phase. Assuming four, $5 \mathrm{~kW}$ class thrusters per spacecraft, 45 day orbit insertion times, and 15 years of stationkeeping the comparison of the performance of fixed $I_{s p}$ and a variable $I_{s p}$ propulsion systems is made.

Tables 2 and 3 show the net mass available for a 45 day orbit insertion, 15 year stationkeeping mission with different propulsion systems. Net mass refers to end-of-life spacecraft mass less dry propulsion system. Regardless of technology, net mass gains of approximately $100 \mathrm{~kg}$ compared to state-of-art Hall and ion systems are possible for 45 day insertion using variable $I_{s p}$ Hall and ion systems. An optimal $I_{s p}$ for the insertion was found to maximize payload mass. Stationkeeping $I_{s p}$ was set to a high value to minimize stationkeeping fuel. 
Table 2. Ion systems performance.

\begin{tabular}{|c|c|c|c|}
\hline $\begin{array}{c}\text { Ion 45 Day } \\
\text { Orbit Insertion }\end{array}$ & SOA ion & $\begin{array}{c}\text { Optimal } \\
\text { Transfer, } \\
\text { High SK } \\
\text { Variable } \\
\text { Isp ion }\end{array}$ & $\begin{array}{c}\text { Relaxed } \\
\text { Transfer, } \\
\text { High SK } \\
\text { Variable } \\
\text { Isp ion }\end{array}$ \\
\hline Net Mass & $2097 \mathrm{~kg}$ & $2198 \mathrm{~kg}$ & $2191 \mathrm{~kg}$ \\
\hline $\begin{array}{c}\text { Additional Net } \\
\text { Mass }\end{array}$ & $0 \mathrm{~kg}$ & $101 \mathrm{~kg}$ & $94 \mathrm{~kg}$ \\
\hline Transfer Isp & $3800 \mathrm{~s}$ & $2066 \mathrm{~s}$ & $2400 \mathrm{~s}$ \\
\hline $\begin{array}{c}\text { Stationkeeping } \\
\text { Isp }\end{array}$ & $3800 \mathrm{~s}$ & $5000 \mathrm{~s}$ & $5000 \mathrm{~s}$ \\
\hline $\begin{array}{c}\text { Transfer Fuel } \\
\text { Throughput / 5 } \\
\mathrm{kW} \text { Thruster }\end{array}$ & $18 \mathrm{~kg} / \mathrm{thr}$ & $46 \mathrm{~kg} / \mathrm{thr}$ & $37 \mathrm{~kg} / \mathrm{thr}$ \\
\hline $\begin{array}{c}\text { Stationkeeping } \\
\text { Fuel Throughput } \\
\text { / 5 kW Thruster }\end{array}$ & $13 \mathrm{~kg} / \mathrm{thr}$ & $10 \mathrm{~kg} / \mathrm{thr}$ & $10 \mathrm{~kg} / \mathrm{thr}$ \\
\hline
\end{tabular}

Table 3. Hall systems performance.

\begin{tabular}{|c|c|c|c|}
\hline $\begin{array}{c}\text { Hall 45 Day } \\
\text { Orbit Insertion }\end{array}$ & SOA Hall & $\begin{array}{c}\text { Optimal } \\
\text { Transfer, } \\
\text { High } \\
\text { NSSK } \\
\text { Variable } \\
\text { Isp Hall }\end{array}$ & $\begin{array}{c}\text { Optimal } \\
\text { Transfer, } \\
\text { Relaxed } \\
\text { NSSK } \\
\text { Variable Isp } \\
\text { Hall }\end{array}$ \\
\hline Net Mass & $2120 \mathrm{~kg}$ & $2222 \mathrm{~kg}$ & $2202 \mathrm{~kg}$ \\
\hline $\begin{array}{c}\text { Additional Net } \\
\text { Mass }\end{array}$ & $0 \mathrm{~kg}$ & $102 \mathrm{~kg}$ & $82 \mathrm{~kg}$ \\
\hline Transfer Isp & $1500 \mathrm{~s}$ & $1677 \mathrm{~s}$ & $1677 \mathrm{~s}$ \\
\hline $\begin{array}{c}\text { Stationkeeping } \\
\text { Isp }\end{array}$ & $1500 \mathrm{~s}$ & $4000 \mathrm{~s}$ & $3000 \mathrm{~s}$ \\
\hline $\begin{array}{c}\text { Transfer Fuel } \\
\text { Throughput / 5 } \\
\mathrm{kW} \text { Thruster }\end{array}$ & $77 \mathrm{~kg} / \mathrm{thr}$ & $66 \mathrm{~kg} / \mathrm{thr}$ & $66 \mathrm{~kg} / \mathrm{thr}$ \\
\hline $\begin{array}{c}\text { Stationkeeping } \\
\text { Fuel Throughput } \\
\text { / 5 kW Thruster }\end{array}$ & $40 \mathrm{~kg} / \mathrm{thr}$ & $15 \mathrm{~kg} / \mathrm{thr}$ & $21 \mathrm{~kg} / \mathrm{thr}$ \\
\hline
\end{tabular}

For the ion system another case was added, limiting the lower orbit insertion $I_{s p}$ to 2400 seconds, an easier operating point from the aspect of life. The loss of payload is small. Limiting the lower $I_{s p}$ to 3000 seconds almost halves the potential mass gain as shown in Figure 3.

Figure 3 also shows the optimum insertion $I_{\mathrm{sp}}$ of 2066 seconds and the impact of lowering the $I_{s p}$ any further (1800s). The performance is decreased due to the ion's efficiency performance at the lower specific impulses. Relaxing the higher, stationkeeping $I_{s \mathrm{sp}}$ from 5000 seconds to 3800 seconds loses about $12 \mathrm{~kg}$ regardless of insertion $I_{s p}$. Fixing the specific impulses for both the insertion and stationkeeping phases to 3000 seconds only increases the performance by $37 \mathrm{~kg}$.

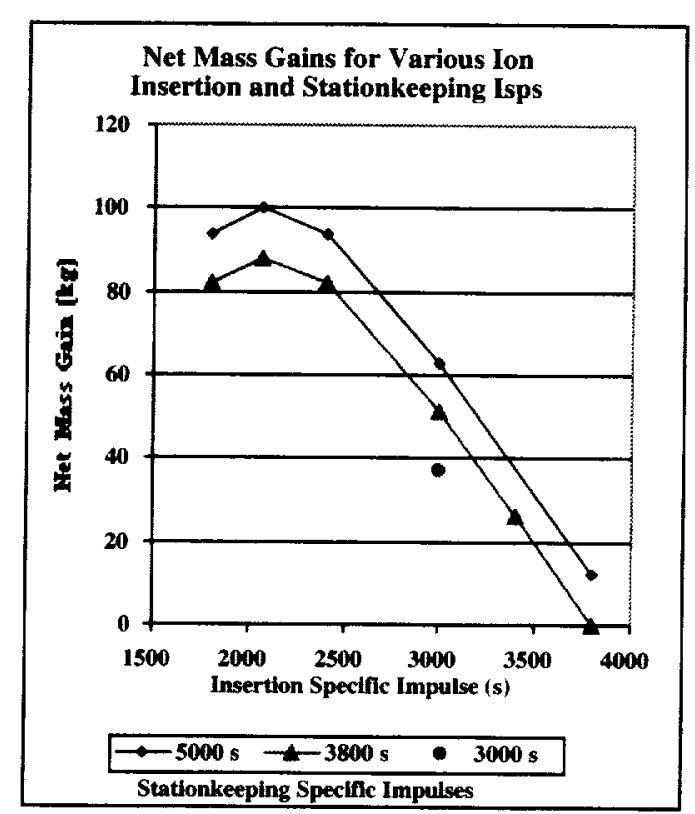

Figure 3. GEO ion net mass gains.

As shown in Tables 2 and 3 the optimal $I_{s p}$ for the orbit insertion phase of the Hall thruster (1677s) is less than that of the ion thruster (2066s) due to their different efficiency vs. $I_{b p}$ performance. For the best Hall case the stationkeeping $I_{\mathrm{sp}}(4000 \mathrm{~s})$ was set to a very high level to show the potential benefit. Another Hall case is shown in Table 3 with reduced $I_{s p}(3000 s)$ to better demonstrated values. The payload was reduced but still notable compared to the single setpoint case. Using a single optimal $I_{s p}(2025 \mathrm{~s})$ for both missions reduces the net mass gain to $31 \mathrm{~kg}$ as shown in Figure 4. Raising the single point $I_{s p}$ higher ( $2400 \mathrm{~s}$ for example) delivers less mass. Figure 4 also graphically shows the gains possible by raising the stationkeeping $I_{s p}$.

The optimal transfer $I_{s p}$ set-points and required fuel throughputs for each phase are also shown in Tables 2 and 3. Compared to the SOA ion case over two times the transfer propellant is needed per thruster, while the stationkeeping throughput requirement is slightly less. The Hall thruster has a reduced stationkeeping throughput requirement but at a much higher $I_{s p}$ operating point.

In comparing the net mass performance of the Hall and ion VIPS one finds that the Hall system slightly outperforms the ion system. Both systems improve payload masses compared to state-of-art Hall and ion by almost $5 \%$ or $100 \mathrm{~kg}$ without requiring any longer transfer times. Longer transfer times should allow even 


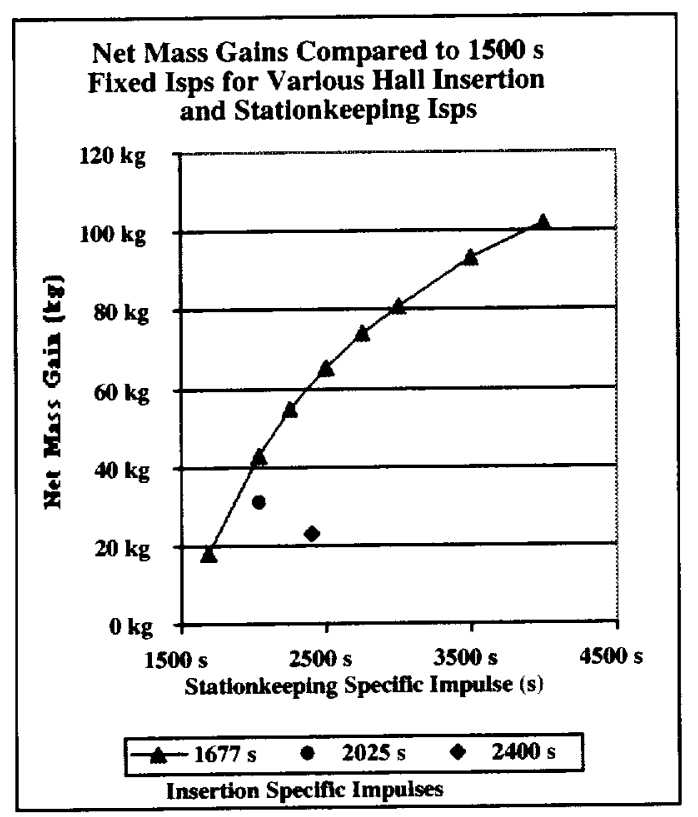

Figure 4. GEO Hall net mass gains.

more mass advantage. Each kilogram of extra mass can add more payload revenue over the 15 years of operation.

\section{LEO to GEO Reusable Tug Missions}

The concept of a reusable electric propulsion tug to deliver spacecraft from a low earth parking orbit to GEO and return for another payload has been explored by many authors. ${ }^{13-16}$ Delivered payload improvements of greater than $100 \%$ are possible compared to chemical propulsion systems. Some authors have suggested using a two $I_{\mathrm{sp}}$ system, a low $I_{\mathrm{sp}}$ for quick delivery to GEO, and a high $I_{s p}$ for return of the lightened tug. ${ }^{15.16}$ The higher $I_{s p}$ will reduce the mass of the return fuel to be carried all the way to GEO.

The GEO tug system and mission assumptions made here are similar to those defined in reference 16 . Power level is set at $100 \mathrm{~kW}$ and a combined starting mass of $10,000 \mathrm{~kg}$, which includes payload, fuel, and dry tug mass is assumed. Other tug assumptions are shown in Table 4.

Table 4. GEO tug propulsion.

\begin{tabular}{|c|c|c|}
\hline $100 \mathrm{~kW}$ GEO Tug Systems & ion & Hall \\
\hline $\begin{array}{c}\text { Power into Power } \\
\text { Processor (per thruster) }\end{array}$ & $50 \mathrm{~kW}$ & $50 \mathrm{~kW}$ \\
\hline $\begin{array}{c}\text { Per Thruster Mass incl } \\
\text { gimbal,support,controller }\end{array}$ & $97 \mathrm{~kg}$ & $80 \mathrm{~kg}$ \\
\hline PPU, Feed System, & $\begin{array}{c}3.2 \\
\text { Cabling, Thermal }\end{array}$ & $\begin{array}{c}2.7 \\
\mathrm{~kg} / \mathrm{kW}\end{array}$ \\
\hline Xenon tankage & 0.1 & 0.1 \\
\hline
\end{tabular}

The starting orbit is set at $400 \mathrm{~km}, 28.5^{\circ}$ and the target orbit is $35786 \mathrm{~km}, 0^{\circ}$. After payload delivery the tug returns to LEO for another payload and fuel module (it is desirable for the thrusters to be multiple use). The analysis assumes Edelbaum steering and assesses the impact of shadowing and earth oblatness. Solar array degradation is assumed negligible since an advanced radiation resistant array would be necessary for such a multi-mission system.

Top level mission performance for expendable systems is defined as delivered payload versus delivery time. For reusable tug systems two other parameters are important: return time and refit mass. Return time is important since no other payloads can be delivered until return to LEO. Refit mass includes the fuel which must be resupplied to the tug upon its return to LEO. Such mass will impact launch costs.

Table 5 shows these parameters for the sample mission. The results are for relative comparison of the fixed and variable $I_{s p}$ systems and are not optimized. For the baseline Hall thruster an $I_{s p}$ of 1500 seconds is assumed for the outbound and inbound mission. By changing only the inbound $I_{s p}$ to 3500 seconds with the variable $I_{s p}$ thrusters, the delivery mission time is preserved. Payload is increased by $483 \mathrm{~kg}$ (almost $14 \%$ ) at the expense of a $15 \%$ longer return time Choosing a higher fixed $I_{s p}$ with the same round trip time as the variable $I_{s p}$ case $(1800 \mathrm{~s})$ increases delivery time by two weeks and provides relatively no more payload. By changing the outbound $I_{s p}$ to 1300 seconds and the inbound $I_{s p}$ to 2600 seconds, the delivered payload and round trip time are nearly the same as the fixed 1500 second case but the delivery time is decreased by a week.

The results for the ion case are similar as shown in Table 6. For the baseline ion thruster an $I_{s p}$ of $\mathbf{3 0 0 0}$ seconds is assumed for the outbound and inbound mission. By changing only the outbound $\mathrm{I}_{\mathrm{sp}}$ to 5000 seconds with the variable $I_{s p}$ ion thrusters, the delivery mission time is preserved. Payload is increased by 252 $\mathrm{kg}$ at the expense of a $15 \%$ longer return time. By changing the outbound $I_{s p}$ to 2700 seconds and the inbound $I_{s p}$ to 3900 seconds, the delivered payload and round trip time is almost the same as the fixed 3000 second case but the delivery time is decreased by almost two weeks. 
Table 5. GEO tug Hall results.

\begin{tabular}{|c|c|c|c|c|}
\hline GEO Tug & $\begin{array}{c}\text { Xe Hall } \\
50 \mathrm{~kW} \\
1500 \mathrm{~s} / \\
1500 \mathrm{~s}\end{array}$ & $\begin{array}{c}\text { Xe Hall 50 } \\
\mathrm{kW} 1500 \mathrm{~s} / \\
3500 \mathrm{~s}\end{array}$ & $\begin{array}{c}\text { Xe Hall } \\
50 \mathrm{~kW} \\
1800 \mathrm{~s} / \\
1800 \mathrm{~s}\end{array}$ & $\begin{array}{c}\text { Xe Hall 50 } \\
\mathrm{kW} 1300 \mathrm{~s} \\
/ 2600 \mathrm{~s}\end{array}$ \\
\hline $\begin{array}{c}\text { Payload } \\
\text { Mass }\end{array}$ & 3517 & 4000 & 4002 & 3521 \\
\hline $\begin{array}{c}\text { Additional } \\
\text { Payload } \\
\text { Mass }\end{array}$ & 0 & 483 & 485 & 4 \\
\hline $\begin{array}{c}\text { Total Fuel } \\
\text { Mass }\end{array}$ & $4168 \mathrm{~kg}$ & $3718 \mathrm{~kg}$ & $3716 \mathrm{~kg}$ & $4163 \mathrm{~kg}$ \\
\hline $\begin{array}{c}\text { Outbound } \\
\text { Trip Time }\end{array}$ & $104 \mathrm{~d}$ & $104 \mathrm{~d}$ & $118 \mathrm{~d}$ & $97 \mathrm{~d}$ \\
\hline $\begin{array}{c}\text { Round Trip } \\
\text { Time }\end{array}$ & $130 \mathrm{~d}$ & $150 \mathrm{~d}$ & $150 \mathrm{~d}$ & $130 \mathrm{~d}$ \\
\hline $\begin{array}{c}\text { Outbound } \\
\text { Isp }\end{array}$ & $1500 \mathrm{sec}$ & $1500 \mathrm{sec}$ & $1800 \mathrm{sec}$ & $1300 \mathrm{sec}$ \\
\hline Inbound Isp & $1500 \mathrm{sec}$ & $3500 \mathrm{sec}$ & $1800 \mathrm{sec}$ & $2600 \mathrm{sec}$ \\
\hline $\begin{array}{c}\text { Outbound } \\
\text { Throughput } \\
\text { / Thruster }\end{array}$ & $1653 \mathrm{~kg}$ & $1653 \mathrm{~kg}$ & $1422 \mathrm{~kg}$ & $1854 \mathrm{~kg}$ \\
\hline $\begin{array}{c}\text { Inbound } \\
\text { Throughput } \\
\text { Thruster }\end{array}$ & $431 \mathrm{~kg}$ & $206 \mathrm{~kg}$ & $436 \mathrm{~kg}$ & $228 \mathrm{~kg}$ \\
\hline
\end{tabular}

Table 6. GEO tug ion results.

\begin{tabular}{|c|c|c|c|c|}
\hline GEO Tug & $\begin{array}{c}\text { Xe Ion S0 } \\
\mathrm{kW} \mathrm{3000} \\
\mathrm{s} / 3000 \mathrm{~s}\end{array}$ & $\begin{array}{c}\text { Xe Ion 50 } \\
\mathrm{kW} 3000 \mathrm{~s} / \\
5000 \mathrm{~s}\end{array}$ & $\begin{array}{c}\text { Xe Ion 50 } \\
\mathrm{kW} 3515 \\
\mathrm{~s} / 3515 \mathrm{~s}\end{array}$ & $\begin{array}{c}\text { Xe Ion 50 } \\
\mathrm{kW} 2700 \mathrm{~s} \\
/ 3900 \mathrm{~s}\end{array}$ \\
\hline $\begin{array}{c}\text { Payload } \\
\text { Mass }\end{array}$ & 4950 & 5202 & 5225 & 4954 \\
\hline $\begin{array}{c}\text { Additional } \\
\text { Payload } \\
\text { Mass }\end{array}$ & 0 & 252 & 275 & 4 \\
\hline $\begin{array}{c}\text { Total Fuel } \\
\text { Mass }\end{array}$ & $2563 \mathrm{~kg}$ & $2283 \mathrm{~kg}$ & $2257 \mathrm{~kg}$ & $2559 \mathrm{~kg}$ \\
\hline $\begin{array}{c}\text { Outbound } \\
\text { Trip Time }\end{array}$ & $168 \mathrm{~d}$ & $168 \mathrm{~d}$ & $190 \mathrm{~d}$ & $157 \mathrm{~d}$ \\
\hline $\begin{array}{c}\text { Round Trip } \\
\text { Time }\end{array}$ & $238 \mathrm{~d}$ & $274 \mathrm{~d}$ & $274 \mathrm{~d}$ & $238 \mathrm{~d}$ \\
\hline $\begin{array}{c}\text { Outbound } \\
\text { Isp }\end{array}$ & $3000 \mathrm{sec}$ & $3000 \mathrm{sec}$ & $3515 \mathrm{sec}$ & $2700 \mathrm{sec}$ \\
\hline Inbound Isp & $3000 \mathrm{sec}$ & $5000 \mathrm{sec}$ & $3515 \mathrm{sec}$ & $3900 \mathrm{sec}$ \\
\hline $\begin{array}{c}\text { Outbound } \\
\text { Throughput } \\
\text { / Thruster }\end{array}$ & $909 \mathrm{~kg}$ & $909 \mathrm{~kg}$ & $787 \mathrm{~kg}$ & $1000 \mathrm{~kg}$ \\
\hline $\begin{array}{c}\text { Inbound } \\
\text { Throughput } \\
\text { / Thruster }\end{array}$ & $372 \mathrm{~kg}$ & $232 \mathrm{~kg}$ & $341 \mathrm{~kg}$ & $280 \mathrm{~kg}$ \\
\hline
\end{tabular}

Both the Hall and the ion system can benefit from variable $I_{s p}$ (two set-points may be sufficient) for the tug mission. More payload may be added without increasing delivery time - an important parameter when financing satellites. ${ }^{9}$ Alternatively, delivery time may be decreased without sacrificing payload or round trip time. It should be mentioned that to decrease costs it is desirable to run the thrusters over many flights which would correspondingly increase the throughput per thruster shown in Tables 5 and 6.

\section{Interplanetary Missions}

With the successful flight of the NSTAR propulsion system on Deep-Space One, ion propulsion has established itself as the advanced propulsion of choice for the next generation of interplanetary probes. ${ }^{17}$ Some authors have suggested using Hall thrusters for interplanetary missions. ${ }^{18.19}$ Gefert, Hack and Kerslake innovatively use Hall thrusters to provide most of the escape $\Delta \mathrm{V}$, allowing a chemical system to finish the mission. ${ }^{18}$ Another paper by Leifer suggested using both Hall and ion thrusters, the Hall in geocentric space, and the ion for the heliocentric portion of the mission. ${ }^{20}$ Most of the scenarios, including Leifer, enabled the use of smaller and less expensive launch vehicles when compared to all chemical missions.

The mission concept by Leifer is a good example to show the advantage of the Hall and ion VIPS since both propulsion systems are on-board.

Several launch vehicle options were considered for launching the Europa Orbiter spacecraft and electric propulsion system. The Delta III launch option will be compared here. The basic concept starts in an elliptical Earth orbit and uses a five, $\left(3.4 \mathrm{~kW}, 1800 \mathrm{sec} \mathrm{I}_{\mathrm{sp}}\right)$ Hall thruster stage to take the $18 \mathrm{~kW}$ spacecraft to escape. At this point the Hall propulsion system stage is separated and an ion stage (or high $\mathrm{I}_{\mathrm{sp}}$ Hall stage) takes over to perform a Venus-Venus Gravity Assist to deliver the spacecraft to Jupiter. A chemical stage is then used to place the payload in Europa orbit.

Two options were explored for the Delta III launch, one using a 3 ion thruster heliocentric propulsion system and another using a 2 High $I_{s p}$ Hall thruster propulsion system. Both options assumed a 5 thruster Hall geocentric space kick stage.

Assuming the two options from Leifer as baselines, other cases using either a Hall or ion VIPS may be used. The elimination of the disposed geocentric stage is sought, thereby eliminating the need for two different propulsion system types and an expendable Hall thruster stage. For the Hall / ion option the Hall geocentric stage is removed and the geocentric phase and heliocentric phases are performed by five ion VIPS. For the other option, using two different Hall thrusters, the geocentric stage will be removed and five Hall VIPS will be used for the geocentric and 
heliocentric phases. $I_{s p}$ and efficiency performance for the variable $I_{s p}$ systems is kept at the specific impulses and efficiencies assumed by Liefer, not given earlier in this paper, to simplify this analysis.

Table 7 shows the staged (from Leifer) and the nonstaged variable $I_{s p}$ options side by side. For the nonstaged case extra thrusters were added to the main spacecraft and nothing was dropped at the end of the geocentric phase. The variable $I_{\mathrm{sp}}$ thrusters, whether Hall or ion, performed the same mission at the specific impulses of the staged mission, 1800 seconds for the geocentric phase and 3100 seconds for the heliocentric phase. Trip times should be similar to those of the baseline.

Even though the non-staged option carries the dry fuel tanks and the five thrusters used in the geocentric phase, it delivers 9 to $13 \%$ more payload to the final orbit compared to the staged options. It does this by reducing the number of needed thruster systems from seven or eight to five.

In addition to the payload advantages, the non-staged approach should cost less since fewer propulsion systems would be needed. The non-staged approach would also have built-in redundancy since extra thrusters from the geocentric phase could be used in the helicentric phase. Alternately, the heliocentric fuel throughput required of each thruster could be reduced since more thrusters are carried. Fuel throughput per thruster for each phase is also shown in Table 7. Each of the VIPS, Hall or Ion, would have to provide these throughputs for the low and high $I_{s p}$ phases of the mission.

This application of VIPS should be explored further for other interplanetary missions, especially those requiring low $\mathrm{I}_{\mathrm{sp}}$ operation around earth and/or near its target.

\section{Summary of Mission Requirements}

Each of the mission examples demonstrated how a constant power, variable $I_{s p}$ system provided mission benefits compared to existing Hall or ion propulsion systems. The $I_{s p}$ range and required fuel throughput from each mission is shown in Table 8. The development of an ion or Hall thruster for VIPS applications requires efficiency and fuel throughput improvements at throttling conditions beyond the demonstrated envelopes. The $I_{s p}$ variation is mainly provided by changing the accelerating voltage of the device. Consequently, power processing units need to be designed to handle this change in voltage but still
Table 7. Europa Orbiter, negative $C 3$ ion and Hall results.

\begin{tabular}{|c|c|c|c|c|}
\hline $\begin{array}{l}\text { Staged vs Non- } \\
\text { Staged Hall//on }\end{array}$ & $\begin{array}{c}5 \text { Hall } / 3 \\
\text { Ion }\end{array}$ & $\begin{array}{l}\text { Non- } \\
\text { Staged, }\end{array}$ & $\begin{array}{c}5 \text { Hall } / 2 \\
\text { Hall }\end{array}$ & $\begin{array}{l}\text { Non- } \\
\text { Staged, }\end{array}$ \\
\hline $\begin{array}{l}\text { Systems for } \\
\text { Europa }\end{array}$ & $\begin{array}{l}\text { Staged } \\
\text { from ref. }\end{array}$ & $\begin{array}{c}\text { Five } 3.4 \\
\mathrm{~kW}\end{array}$ & $\begin{array}{l}\text { Staged } \\
\text { from ref. }\end{array}$ & $\begin{array}{c}\text { Five } 3.4 \\
\mathrm{~kW}\end{array}$ \\
\hline Orbiter/Lander & 20 & $\begin{array}{l}\text { Variable } \\
\text { Isp Ion } \\
\text { Thrusters }\end{array}$ & 20 & $\begin{array}{c}\text { Variable } \\
\text { Isp Hall } \\
\text { Thrusters }\end{array}$ \\
\hline Launch Mass & $3735 \mathrm{~kg}$ & $3735 \mathrm{~kg}$ & $3735 \mathrm{~kg}$ & $3735 \mathrm{~kg}$ \\
\hline $\begin{array}{l}\text { Geocentric dry } \\
\text { Stg Mass }\end{array}$ & $37 \mathrm{l} \mathrm{kg}$ & $0 \mathrm{~kg}$ & $371 \mathrm{~kg}$ & $0 \mathrm{~kg}$ \\
\hline $\begin{array}{l}\text { Geocentric Stg } \\
\text { Tank Mass }\end{array}$ & $132 \mathrm{~kg}$ & $132 \mathrm{~kg}$ & $132 \mathrm{~kg}$ & $132 \mathrm{~kg}$ \\
\hline $\begin{array}{c}\text { Geocentric stg } \\
\text { Isp }\end{array}$ & 1800 & 1800 & 1800 & 1800 \\
\hline Geocentric $\Delta V$ & $5591 \mathrm{~m} / \mathrm{s}$ & $5591 \mathrm{~m} / \mathrm{s}$ & $5591 \mathrm{~m} / \mathrm{s}$ & $5591 \mathrm{~m} / \mathrm{s}$ \\
\hline $\begin{array}{l}\text { Geocentric Fuel } \\
\text { Mass }\end{array}$ & $1014 \mathrm{~kg}$ & $1014 \mathrm{~kg}$ & $1014 \mathrm{~kg}$ & $1014 \mathrm{~kg}$ \\
\hline mass at escape & $2721 \mathrm{~kg}$ & $2721 \mathrm{~kg}$ & $2721 \mathrm{~kg}$ & $2721 \mathrm{~kg}$ \\
\hline $\begin{array}{l}\text { escape mass less } \\
\text { stage }\end{array}$ & $2350 \mathrm{~kg}$ & $2721 \mathrm{~kg}$ & $2350 \mathrm{~kg}$ & $2721 \mathrm{~kg}$ \\
\hline Heliocentric Isp & 3100 & 3100 & 3100 & 3100 \\
\hline $\begin{array}{c}\text { Eqv. } \\
\text { Heliocentric } \Delta V\end{array}$ & $6033 \mathrm{~m} / \mathrm{s}$ & $6033 \mathrm{~m} / \mathrm{s}$ & $6033 \mathrm{~m} / \mathrm{s}$ & $6033 \mathrm{~m} / \mathrm{s}$ \\
\hline $\begin{array}{c}\text { Heliocentric Fuel } \\
\text { Mass }\end{array}$ & $423 \mathrm{~kg}$ & $490 \mathrm{~kg}$ & $423 \mathrm{~kg}$ & $490 \mathrm{~kg}$ \\
\hline $\begin{array}{l}\text { Heliocentric } \\
\text { Tank Mass }\end{array}$ & $55 \mathrm{~kg}$ & $64 \mathrm{~kg}$ & $55 \mathrm{~kg}$ & $64 \mathrm{~kg}$ \\
\hline $\begin{array}{l}\text { dry Helio SEP } \\
\text { sys (with solar } \\
\text { Arrays) }\end{array}$ & $871 \mathrm{~kg}$ & $1040 \mathrm{~kg}$ & $832 \mathrm{~kg}$ & $1039 \mathrm{~kg}$ \\
\hline Mass at Jupiter & $1927 \mathrm{~kg}$ & $2231 \mathrm{~kg}$ & $1927 \mathrm{~kg}$ & $2231 \mathrm{~kg}$ \\
\hline Mnet Jupiter & $1056 \mathrm{~kg}$ & $1191 \mathrm{~kg}$ & $1095 \mathrm{~kg}$ & $1192 \mathrm{~kg}$ \\
\hline $\begin{array}{c}\text { Mnet Europa } \\
\text { (chem } \Delta V=2.7 \\
\mathrm{~km} / \mathrm{s} \text { ) }\end{array}$ & $453 \mathrm{~kg}$ & $511 \mathrm{~kg}$ & $469 \mathrm{~kg}$ & $511 \mathrm{~kg}$ \\
\hline $\begin{array}{c}\text { Added Payload } \\
\text { Mass }\end{array}$ & & $58 \mathrm{~kg}$ & & $42 \mathrm{~kg}$ \\
\hline \multicolumn{2}{|c|}{$\begin{array}{l}\text { Low Isp Fuel Throughput / } \\
\text { thruster }\end{array}$} & $203 \mathrm{~kg}$ & & $203 \mathrm{~kg}$ \\
\hline \multicolumn{2}{|c|}{$\begin{array}{l}\text { High Isp Fuel Throughput / } \\
\text { thruster }\end{array}$} & 98 & & $98 \mathrm{~kg}$ \\
\hline
\end{tabular}

provide sufficient power. The NSTAR power processing unit does provide voltage steps establishing the technological feasibility. Except for the Europa mission, the variable $I_{s p}$, constant power systems may only need two setpoints, which would make power processor and thruster design easier.

Table 8 also indicates that the Hall thruster technology needs to reach 3000 to 3500 seconds to realize the potential mass and/or other savings of each mission. For the earth orbit missions the higher $I_{s p}$ fuel throughput for the Hall thruster needs to be $\sim 4 \mathrm{~kg}$ of fuel per $\mathrm{kW}$ of thruster power, about 12 to $30 \%$ of the throughput at more nominal specific impulses. Such 
throughputs at high specific impulses need to be in addition to the low $I_{s p}$ throughput but may not be unreasonable. To handle an engine out condition the value for the GEO stationkeeping phase may need to be doubled. The throughput of the tugs only represent one round trip in Table 3; the throughput would need to be increased by the number of round trips performed. The Europa mission must process substantially more fuel and may require life enhancing materials or two-stage engines.

The ion thruster operates between 2400 to 3000 seconds except for the Europa orbiter. At low specific impulse ( $<3000$ seconds) the ion accelerating voltage no longer provides sufficient beamlet focusing to prevent direct beam impingement on the accelerator grid. The phenomena severely curtails the life for the ion optics. Fuel throughput requirements for the ion VIPS at lower $I_{s p}$ points for the earth orbit missions seem reasonable. Again the Europa orbiter case would require the greatest life enhancement of the three missions.

The ion thruster has a reduced throughput capability at low specific impulses due to grid erosion as discussed above. Hall thruster throughput limits are predicted to be reduced at higher specific impulses due to the higher energy of ions which in turn cause faster erosion of the thruster wall. ${ }^{21}$ Some possibilities for alleviating these lifetime or fuel throughput limitations include advanced materials for ion thrusters or an additional acceleration stage (two-stage) for Hall thrusters.

\section{Conclusions}

The use of electrostatic rockets with variable $I_{s p}$ at constant power levels can provide multiple mission benefits compared to state-of-art electrostatic propulsion technology. For geosynchronous spacecraft approximately $100 \mathrm{~kg}$ additional payload mass may be added without changing orbit insertion times. Reusable LEO to GEO tugs can use variable $I_{\mathrm{sp}}$ devices to reduce the return fuel mass and add almost $15 \%$ payload spacecraft mass while preserving delivery times. A Europa Orbiter mission can also add 8-13\% payload mass using variable $I_{s p}$ systems.

The real challenge in developing such variable $I_{s p}$ devices is providing sufficient lifetime over the $I_{s p}$ operation range. Hall thrusters will need to demonstrate adequate fuel throughput at high specific impulses, while ion thrusters must have better fuel throughput for lower $I_{s p}$ operation.

Table 8. Summary of $I$ and fuel throughput requirements.

\begin{tabular}{|c|c|c|c|c|c|c|c|}
\hline System/Mission & $\begin{array}{c}\text { Thruster } \\
\text { Power }\end{array}$ & Low Isp & High Isp & $\begin{array}{c}\text { Low Isp fuel } \\
\text { throughput }\end{array}$ & $\begin{array}{c}\text { High Isp fuel } \\
\text { throughput }\end{array}$ & $\begin{array}{c}\text { Low Isp fuel } \\
\text { throughput/kW } \\
\text { Thruster Power }\end{array}$ & $\begin{array}{c}\text { High Isp fuel } \\
\text { throughput/kW } \\
\text { Thruster Power }\end{array}$ \\
\hline $\begin{array}{c}\text { Hall 45 Day Orbit } \\
\text { Insertion }\end{array}$ & $5 \mathrm{~kW}$ & $1677 \mathrm{~s}$ & $\mathbf{3 0 0 0 \mathrm { s }}$ & $66 \mathrm{~kg} / \mathrm{thr}$ & $21 \mathrm{~kg} / \mathrm{thr}$ & $13.2 \mathrm{~kg} / \mathrm{kW}$ & $4.1 \mathrm{~kg} / \mathrm{kW}$ \\
\hline $\begin{array}{c}\text { ion 45 Day Orbit } \\
\text { Insertion }\end{array}$ & $5 \mathrm{~kW}$ & $\mathbf{2 4 0 0 \mathrm { s }}$ & $5000 \mathrm{~s}$ & $37 \mathrm{~kg} / \mathrm{thr}$ & $10 \mathrm{~kg} / \mathrm{thr}$ & $7.5 \mathrm{~kg} / \mathrm{kW}$ & $2.0 \mathrm{~kg} / \mathrm{kW}$ \\
\hline $\begin{array}{c}\text { GEO Tug Xe Hall 50 } \\
\mathrm{kW} \text { 1500 / 3500 s }\end{array}$ & $50 \mathrm{~kW}$ & $1500 \mathrm{~s}$ & $3500 \mathrm{~s}$ & $1653 \mathrm{~kg} / \mathrm{thr}$ & $206 \mathrm{~kg} / \mathrm{thr}$ & $33.1 \mathrm{~kg} / \mathrm{kW}$ & $4.1 \mathrm{~kg} / \mathrm{kW}$ \\
\hline $\begin{array}{c}\text { GEO Tug Xe Ion } 50 \\
\mathrm{~kW} 3000 \mathrm{~s} / 5000 \mathrm{~s}\end{array}$ & $50 \mathrm{~kW}$ & $\mathbf{3 0 0 0 \mathrm { s }}$ & $5000 \mathrm{~s}$ & $909 \mathrm{~kg} / \mathrm{thr}$ & $232 \mathrm{~kg} / \mathrm{thr}$ & $18.2 \mathrm{~kg} / \mathrm{kW}$ & $4.6 \mathrm{~kg} / \mathrm{kW}$ \\
\hline $\begin{array}{c}\text { Europa Orbiter Non- } \\
\text { Staged, Five 3.4 kW } \\
\text { Variable Isp Ion } \\
\text { Thrusters }\end{array}$ & $3.4 \mathrm{~kW}$ & $1800 \mathrm{~s}$ & $\mathbf{3 1 0 0 \mathrm { s }}$ & $203 \mathrm{~kg} / \mathrm{thr}$ & $98 \mathrm{~kg} / \mathrm{thr}$ & $59.6 \mathrm{~kg} / \mathrm{kW}$ & $28.8 \mathrm{~kg} / \mathrm{kW}$ \\
\hline $\begin{array}{c}\text { Europa Orbiter Non- } \\
\text { Staged, Five 3.4 kW } \\
\text { Variable Isp Hall } \\
\text { Thrusters }\end{array}$ & $3.4 \mathrm{~kW}$ & $1800 \mathrm{~s}$ & $3100 \mathrm{~s}$ & $203 \mathrm{~kg} / \mathrm{thr}$ & $98 \mathrm{~kg} / \mathrm{thr}$ & $59.6 \mathrm{~kg} / \mathrm{kW}$ & $28.8 \mathrm{~kg} / \mathrm{kW}$ \\
\hline
\end{tabular}




\section{References}

1. Free, B.A. North-South Stationkeeping with Electric Propulsion Using Onboard Battery Power, COMSAT Laboratories, 1980.

2. Spitzer, A., Near Optimal Transfer Orbit Trajectory using Electric Propulsion, Paper AAS95-215, Feb. 1995.

3. Oleson, S.R., Myers, R.M., Advanced Propulsion for Geostationary Orbit Insertion and NorthSouth Station Keeping, NASA TM-107018, AIAA-95-2513, 31st JPC, July 1995.

4. Oleson, S.R, Electric Propulsion for Low Earth Orbit Communication Satellites, 25th International Electric Propulsion Conference, August, 1997, IEPC 97-148.

5. Sauer, Carl Application of solar electric propulsion to future planetary missions, AIAA87-1053 International Electric Propulsion Conference, 19th, Colorado Springs, CO, May 11-13, 1987.

6. Butler, G.W., Yuen, J.L., Tverdokhlebov, S.O., Semenkin, A.V., Jankovsky, R.S., Multi-Mode, High Specific Impulse Hall Thruster Technology, AIAA-2000-3254, $36^{\text {th }}$ Joint Propulsion Conference, July 17-19, 2000.

7. Patterson, Michael J., Low-I sp $_{s p}$ Derated Ion Thruster Operation, NASA TM-105787, $28^{\text {th }}$ Joint Propulsion Conference, July 6-8, 1992.

8. Porte, F., et al., Benefits of Electric Propulsion for Orbit Injection of Communication Spacecraft, Paper AIAA 92-1955, March 1992.

9. Vaughan, C.E., Cassady, R.J., An Updated Assessment of Electric Propulsion Technology for Near-Earth Space Mission, Paper AIAA-92-3202, July 1992.

10. Free, B., High Altitude Orbit Raising with OnBoard Electric Power, IEPC-93-205, Sept. 1993.

11. Oleson, S.R., Myers, R.M., Launch Vehicle and Power Level Impacts on Electric GEO Insertion, AIAA 96-2978, July 1996.

12. Brown, P., A Look at Hughes' New HS 702 Satellite: The New Workhorse, International Space Industry Report, May 15, 2000/Vol. 4 Number 5, p. 8.
13. Holdaway, R., Jansson, R.E., The Feasibility of Geostationary Emplacement of Satellites by Solar Electric Tug, British Interplanetary Society, Journal, vol. 26, Apr. 1973, p 220-227, A73-26260.

14. Meserole, J.S., Launch Costs to GEO Using Solar-Powered Orbit Transfer Vehicles, AIAA93-2219, $29^{\text {th }}$ Joint Propulsion Conference, June 28-30, Monterey, CA.

15. Unpublished, Aerospace Corp. Reuseable Orbit Transfer Vehicle (OTV) Cost Comparison, Nov. 1, 1995.

16. Oleson, S., Advanced Electric Propulsion For Space Solar Power Satellites, 35th Joint Propulsion Conference, June 1999, AIAA-992872.

17. Brophy, J.R., Advanced Ion Propulsion Technology for Solar System Exploration, AIAA-97-2782, 33 ${ }^{\text {rd }}$ Joint Propulsion Conference, July 6-9, 1997.

18. Gefert, L.P., Hack, K.J., Kerslake, T.W., Options for the Human Exploration of Mars Using Solar Electric Propulsion, Proceedings of the Space Technology and Applications International Forum - 1999.

19. Clauss, C.W., Tilley, D.L., Barnhart, D.A., Benefits of Low-Power Stationary Plasma Thruster Propulsion for Small Satellites, Proceedings of the $9^{\text {th }}$ Annual AIAA/USU Conference on Small Satellites, Sept. 1995.

20. Leifer, S., Noca, M., Negative C3 Launch Options for Solar System Exploration, AIAA-98$3925,34^{\text {th }}$ Joint Propulsion Conference, July 12-15, 1998.

21. Clauss, C., et al., Preliminary Study of Possibility to Ensure Large Enough Lifetime of SPT Operating Under Increased Powers, AIAA-97$2789,33^{\text {rd }}$ Joint Propulsion Conference, July 6-9, 1997. 


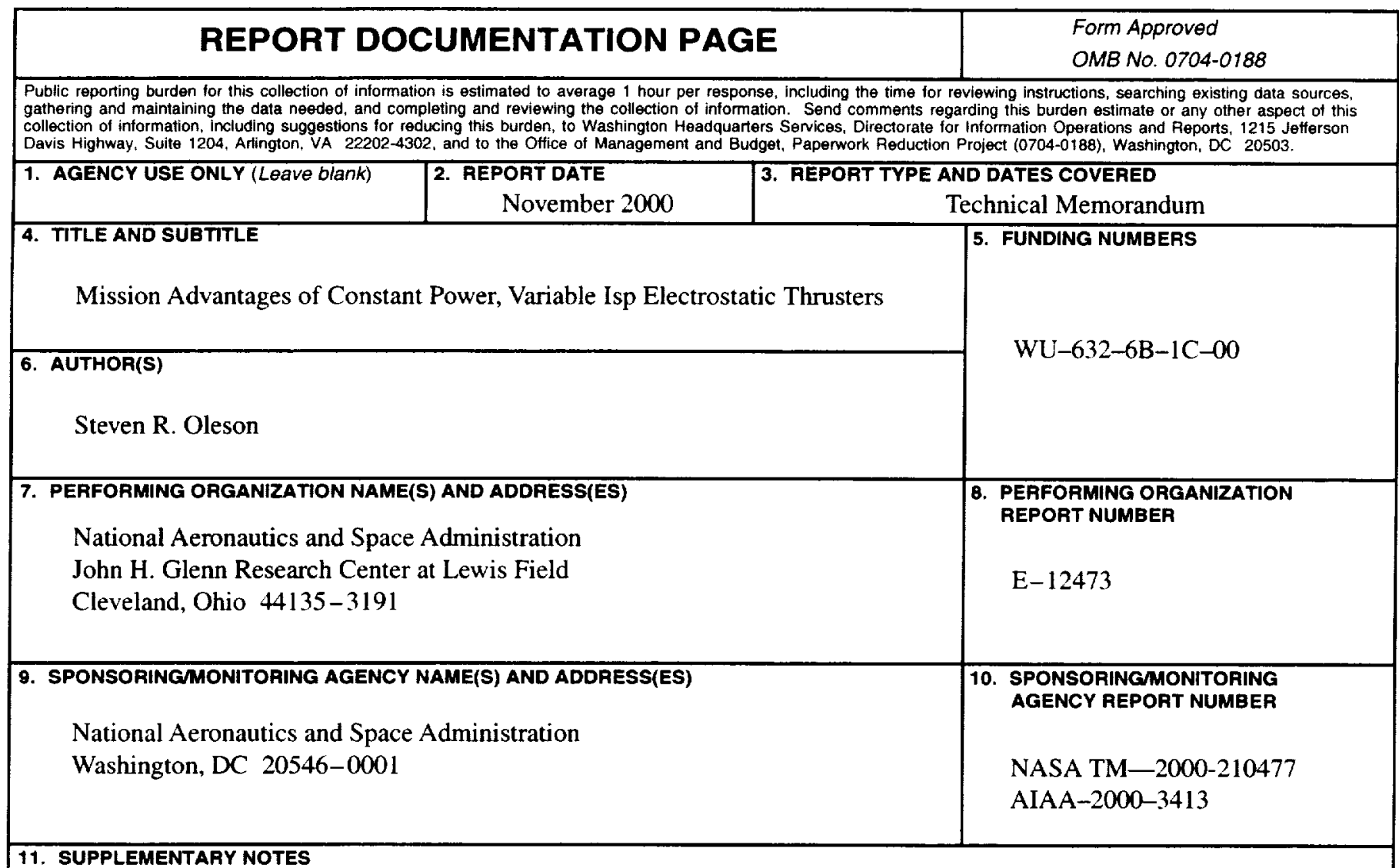

Prepared for the 36th Joint Propulsion Conference and Exhibit cosponsored by the AIAA, ASME, SAE, and ASEE Huntsville, Alabama, July 16-19, 2000. Responsible person, Steven R. Oleson, organization code 6920, 216-977-7426.

12a. DISTRIBUTION/AVAILABILITY STATEMENT

12b. DISTRIBUTTION CODE

Unclassified - Unlimited

Subject Categories: $13,15,16$, and 20

Distribution: Nonstandard

This publication is available from the NASA Center for AeroSpace Information. 301-621-0390.

13. ABSTRACT (Maximum 200 words)

Electric propulsion has moved from stationkeeping capability for spacecraft to primary propulsion with the advent of both the Deep Space One asteroid flyby and geosynchronous spacecraft orbit insertion. In both cases notably more payload was delivered than would have been possible with chemical propulsion. To provide even greater improvements electrostatic thruster performance could be varied in specific impulse, but kept at constant power to provide better payload or trip time performance for different mission phases. Such variable specific impulse mission applications include geosynchronous and low earth orbit spacecraft stationkeeping and orbit insertion, geosynchronous reusable tug missions, and interplanetary probes. The application of variable specific impulse devices is shown to add from 5 to 15 percent payload for these missions. The challenges to building such devices include variable voltage power supplies and extending fuel throughput capabilities across the specific impulse range.

\begin{tabular}{|c|c|c|c|}
\hline \multirow{2}{*}{\multicolumn{3}{|c|}{ Electric propulsion; Trajectory design }} & $\begin{array}{l}\text { 15. NUMBER OF PAGES } \\
15\end{array}$ \\
\hline & & & 16. PRICE CODE \\
\hline
\end{tabular}




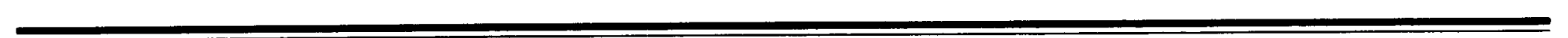

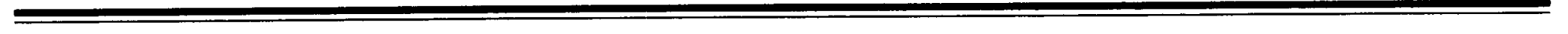

